\title{
The Impact of Personal Remittances, FDI and Exports on Economic Growth: Evidence from West Africa
}

\author{
Jiang Xinying \\ School of Management, Jiangsu University \\ Stephen Oppong* \\ School of Management, Jiangsu University \\ Prince Asare Vitenu-Sackey \\ School of Finance and Economics, Jiangsu University \\ Address: No 301 Xuefu Road, Zhenjiang, 212013, Jiangsu Province, P. R. China
}

\begin{abstract}
The study delves into West African data to assess the impact of personal remittances, FDI and exports on economic growth by applying panel data methodologies on 15 countries from 1991 to 2017 . The study further applied panel fully modified ordinary least square, robust least square, and generalized linear model regression methodologies to make a statistical inference. From the results, it could be ascertained that personal remittances and exports have a strong and positive impact on economic growth. Meanwhile, FDI has a positive impact on economic growth as an individual factor, but with the existence of personal remittances and exports, FDI tends to become negative and significant in West Africa. The study proposes further studies into the area of FDI to unravel the exact relationship it has with economic growth.
\end{abstract}

Keywords: Personal remittances, Foreign direct investment, Exports, Robust least squares, Fully modified ordinary least squares, Generalized linear model

DOI: $10.7176 / \mathrm{EJBM} / 11-23-04$

Publication date: August $31^{\text {st }} 2019$

\section{Introduction}

In the quest to achieve economic development and sustainable growth, economies tend to pursue the same economic agenda which seems to propel economic strides. The picture is different in developing countries due to some domestic macroeconomic policies, human capital development, political stability and country's savings prowess is very critical for economic growth (Keshmeer, 2018; Nayaran and Smyth, 2004; Romer, 1986; Roubini and Wachtel, 1999; Solow, 1956).

In pursuit of finding lasting solutions to this problem, developing countries and economies rely heavily on foreign direct investments to support their economy to develop and expand the sectors of their economies (CalinAdrian et al., 2018). There are mixed outcomes of existing studies on FDI as to the true relationship with economic growth; some studies argue that FDI has a positive impact on economic growth hence it increases economic growth because FDI leads to the accumulation of savings and increases in consumption domestically. Others also argue different inferring that FDI harms economic growth; whereby it decreases in savings (Griffin, 1973). The study draws its motivation from this lacuna to find out the relationship or effect of FDI on West Africa's economic growth.

Africa is predominantly migration prone continent which affects its labor force but remittances usually compensate for the problem of emigration (Blouchoutzi and Nikas, 2014; Olayungbo and Ahmod, 2019). The world's total migration in 2015 stood at 58\% and $42 \%$ to developed countries and developing countries respectively (International Migration Report, 2015) and total remittances as at 2015 stood at \$432 billion out of which $\$ 52$ billion flowed to Africa (Migration and Remittances, 2016). The financial turbulence which occurred in 2008 and 2009 reduced the inflows of remittance worldwide in 2015 which slowed the growth of economies due to this; countries have adopted remittances as a measure of economic growth (Migration and Remittances, 2016). Remittances have a positive effect on economic growth in countries with keen financial intermediation because its effect tends to alleviate poverty, reduce the barriers to funds or credits and increase in consumption (Adleman and Taylor, 1990; Catrinescu et al., 2009; Mundaca, 2009; Nwaogu and Ryan, 2015). Debates spanning across the length and breadth of the globe reports mixed results which some studies argue that too much reliant on remittances cause unemployment. The study draws its motivation from these studies to find out the relationship or effect that remittances have on West Africa's economic growth.

Production of goods and services domestically has a huge effect in an economy; as a result, it creates employment, increases consumption of households and firm which in the long run promotes economic growth. The abundance of production of goods and services generates exports of the excess and the neoclassical school of thought assumes that one of the major measures of economic growth is export hence trade openness transfer goods 
to sectors in which there is a comparative advantage to foster efficiency. These sectors mostly use the unskilled labor which increases employment opportunities and reduces income inequality and also trade liberalization which intends to promote foreign direct inflows of capital and technology (Krueger, 1978; Ram, 1987; Nur et al., 2013). The study draws its motivation from this assertion and seeks to investigate the relationship that exists with export and economic growth in the West Africa region.

The study contributes to existing works of literature significantly to provide fresh evidence on the effect of personal remittances, FDI and export on economic growth in West Africa (Nur et al., 2013; Zizi, 2014; Uwaoma and Michael, 2015; Dietmar and Adela, 2017; Calin-Adrian, 2018; Keshmeer, 2019). The study employs three regression methodologies to make its statistical inference in a robustness context.

The study constitutes five sections namely; section 1 which introduces the study, section 2 contains the literature reviews and section 3 explains the methodology approach and data. Section 4 reports the results and discussion of the outcome whiles the last section (5) concludes the study and proposes some recommendations.

\section{Literature review}

The potential economic effects of remittances, export, and FDI have interested my scholars globally. There have been a lot of studies into these areas of economic empowerment to unravel the exact relationship they have on economic growth and development.

\subsection{Remittances and economic growth nexus}

Remittances have two main theoretical approaches; family approach and portfolio approach. The family approach is when altruistic reasons ginger immigrants to send money back home to subsistence on the part of their family. The portfolio approach is the propensity of remitters to invest in their home countries. These two approaches affirm that remittances propel economic growth and development by the tendency it has to increase consumption and production (OECD, 2006). There have been divided arguments on the effect of remittances on economic growth. Zizi (2014) studied remittances as an economic development factor in CEE countries and concluded that remittances have a positive effect on economic growth. Moreover, Uwaoma and Michael (2015) assert that remittances affect economic growth when it is estimated simultaneously in their study of the impact on FDI, foreign aid and remittance on economic growth in 53 African countries and 34 Latin American and Caribbean countries. Some studies have the conviction that remittances inflows go to the deprived, impoverish and poor families who have relatives abroad hence reduces the level of poverty and income inequality, also as remittances are considered as the second largest inflow of funds into an economy, it tends to act as a source of funding or capital to create and support higher employment, also contribute to the defraying of current account deficit; therefore, it has a positive effect on economic growth and development (Quibria, 1997; Taylor, 1999; Lowell and De La Garza, 2000; Daianu, 2001; Leon-Ledesma and Piracha, 2001:2004; Adams and Page, 2003; Docquier and Rapoport, 2003; Ratha, 2003; Terry et al., 2004; Mundaca, 2009; Bugamelli and Paterno, 2011; Zizi, 2014; Uwoema and Michael, 2015, Dietmar and Adela, 2017; Calin-Adrian et al., 2018, Keshmeer, 2018, Olayungbo and Ahmod, 2019). A section of researchers are of the view that affluent families have the capability of paying the cost involved in emigration and are the people who benefit from remittances, therefore remittances do not benefit the poor to emancipate them from economic hardships. Again, some studies found a negative effect and mixed results of remittances on economic growth (Barajas et al., 2009; Rao and Hassan, 2012; Gijini, 2013).

\subsection{Foreign direct investment and economic growth nexus}

Foreign direct investment has been signaled as a contributor to economic growth due to its externality and spillover and it is a tool for long term sustainable growth (Swan, 1956; Solow, 1956; Romer, 1986; Lucas, 1988; Grossman and Helpman, 1991, Easterly et al., 1994). The reason why FDI is considered as a strong factor of economic growth comes from its characteristics of externality and spillover effect which result from the capital transfer, advanced technologies, employment avenues, and high human capital development. There have some deficits in the production of goods and services and the aggregate economic performance of many developing economies hence the need of foreign direct investments to augment and assist in resolving this canker (Todaro and Smith, 2006). There are four major mediums which FDI streams through to support an economy. Firstly, FDI serves as filling in the gaps of capital shortage through investment in physical and human capital development (Todaro and Smith, 2006). Secondly, FDI helps in the reduction of foreign exchange deficit by the direct inflow of capital from foreign countries which increases a countries ability to pay its foreign debt and improves export competitiveness (Pailwar, 2004). Thirdly, FDI comes into economies by way of investments to bolster production of goods and services and as a result, these firms pay direct and indirect to the host governments which increase their revenue. It also enables governments to embark on their developmental agendas (Todaro and Smith, 2006). Lastly, FDI enables the impartation of knowledge and skills acquisition through new technologies (Wan, 2010). 


\subsection{Export and economic growth nexus}

The abundance of production of goods and services generates exports of the excess and the neoclassical school of thought assumes that one of the major measures of economic growth is export hence trade openness transfer goods to sectors in which there is a comparative advantage to foster efficiency. These sectors mostly use the unskilled labor which increases employment opportunities and reduces income inequality and also trade liberalization which intends to promote foreign direct inflows of capital and technology (Krueger, 1978; Ram, 1987; Nur et al., 2013). Many empirical studies support the export-led growth hypothesis which postulates that exports have a positive effect on economic growth thereby increasing economic growth as a result of exporting more produced goods and services (Ullah et al., 2009; Aditya and Acharyya, 2012). Meanwhile, other researchers do not support the exportled growth hypothesis (Mah, 2005; Pazim, 2009).

Given all these arguments and debates here and there, the study intends to explore further to ascertain whether the arguments of the existing literature are valid and as to which the data of West Africa will affirm. As a matter of importance attached to the study, it has employed three-panel methodologies to make robust estimations and statistically infer on its outcome.

\section{Data and Methodology}

\subsection{Data}

The study employed panel data of seven variables; three independent variables, three control variable and one dependent variable spanning from the period of 1991 to 2017 for 15 West Africa countries. The description of the variables and their sources can be found in table 1. All the variables were transformed into a natural logarithm.

Table 1 Variable Description

\begin{tabular}{lll}
\hline Variable & Description & Source \\
\hline LnFDI & Foreign direct investment, net inflows (\% of GDP) & World Development Indicators \\
LnPR & Personal remittances received (\% of GDP) & World Development Indicators \\
LnEXP & Exports of goods and services (\% of GDP) & World Development Indicators \\
LnINF & Inflation, consumer prices (annual \%) & World Development Indicators \\
LnPOP & Population growth (annual \%) & World Development Indicators \\
LnUME & Unemployment, total (\% of the total labor force) (modeled & \\
P & ILO estimate) & World Development Indicators \\
LnGDP & GDP per capita, PPP (constant 2011 international \$) & World Development Indicators \\
& & World Bank Database \\
\hline
\end{tabular}

Table 2 List of countries for the study

\begin{tabular}{llllll}
\hline No. & Countries & No. & Countries & No. & Countries \\
\hline 1 & Benin & 6 & Ghana & 11 & Nigeria \\
2 & Burkina Faso & 7 & Guinea & 12 & Niger \\
3 & Cabo Verde & 8 & Guinea Bissau & 13 & Senegal \\
4 & Cote d'Ivoire & 9 & Liberia & 14 & Sierra Leone \\
5 & The Gambia & 10 & Mali & 15 & Togo \\
\hline
\end{tabular}

\subsection{Methodology}

The study considered three regression methodologies to perform the analysis to firmly ascertain the true relationship among the variables and to also make statistical inference on the outcome. Therefore, panel unit root tests, co-integration test, correlation test, fully modified ordinary least square, Generalised linear model and Robust least square methodologies are adopted for the study. By using these methodologies, the study believes that the methodologies can examine the driven factors of economic growth in West Africa in the long run estimations. Moreover, the testing of unit root and co-integration means the study tests for the existence of a long-run relationship among the variables. The study uses each independent variable to assess its effect on the dependent variable together with the three control variables (macroeconomic variables). Afterward, all the independent variables are combined in one equation to assess their effect on economic growth with the assumption that there is no real economic scenario of only one variable that has an impact on economic growth. Hence, the models below are considered for the study:

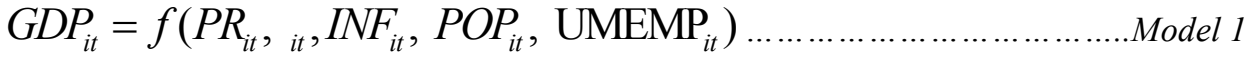

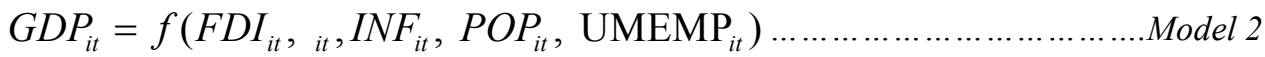

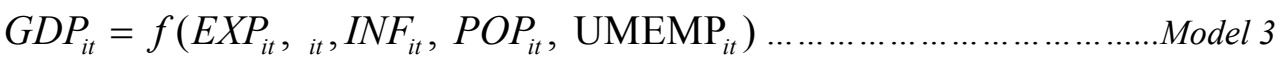

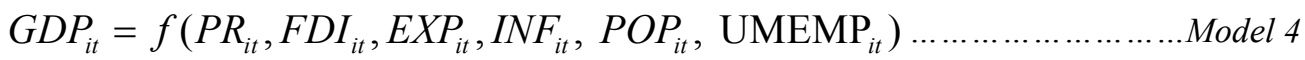


in the equations above (Model $1-4$ ), GDP refers to Gross domestic product per capita as a proxy measure of economic growth, PR stands for Personal remittances, FDI refers to foreign direct investment, EXP stands for Exports of goods and services, INF means Inflation, POP refers to population growth, UNEMP refers to unemployment rate. After taking the logarithm of the variables, the resulting equations or models can be established:

$$
\begin{aligned}
& \text { 爈g }(G D P)_{i t}=\beta_{0}+\beta_{1} \log (P R)_{i t}+\beta_{2} \ln (I N F)_{i t}+\beta_{3} \ln (P O P)_{i t}+\beta_{4} \ln (U M E P)_{i t}+\mu_{i t} \ldots .(1) \\
& \text { 爈g }(G D P)_{i t}=\beta_{0}+\beta_{1} \log (F D I)_{i t}+\beta_{2} \ln (I N F)_{i t}+\beta_{3} \ln (P O P)_{i t}+\beta_{4} \ln (U M E P)_{i t}+\mu_{i t} . .(2) \\
& \text { 爈g }(G D P)_{i t}=\beta_{0}+\beta_{1} \log (E X P)_{i t}+\beta_{2} \ln (I N F)_{i t}+\beta_{3} \ln (P O P)_{i t}+\beta_{4} \ln (U M E P)_{i t}+\mu_{i t} . .(3) \\
& \left.\log (G D P)_{i t}=\beta O+\beta_{1} \log (P R)_{i t}+\beta_{2} \ln (F D I)_{i t}+\beta_{3} \ln (E X P)_{i t}+\beta_{4} \ln (I N F)_{i t}+\beta_{5} \ln (P O P)_{i t}+\beta_{6} \ln (U N E M P)_{i t}+\mu_{i t \ldots \ldots . .(4)}\right)
\end{aligned}
$$

Where $\beta_{0}$ is the intercept, ${ }_{\mathrm{i}}=1 \ldots . \mathrm{I}$ represent the cross section of the countries, $\mathrm{t}=1 \ldots \ldots \mathrm{t}$ represents the time period and $\mu \mathrm{i}$ represents error term (disturbances and other factors that were not considered).

At this juncture, the study begins by testing for panel unit root after making the summary statistics and assessed the normality of the data. The following methods are employed for the unit root tests; Levin-Lin Chu (LLC) Levin et al. (2002), Im-Pesaran Shim (IPS) Im et al. (2003), Fisher Augmented Dickey-Fuller (ADF) and Fisher Philips-Perron (PP) tests (Maddala and $\mathrm{Wu}, 1999$ ). The study considers these three-panel unit root test because of Levin et al. (2002) test statistic for the homogeneity, Im et al. (2003), Fisher ADF and Fisher PP (Maddala and $\mathrm{Wu}, 1999)$ test statistic for heterogeneity. However, the specification proposed by Im et al. (2003) is as follows:

$$
y_{i t}=\rho_{i} y_{i, t-1}+\sigma_{i} x_{i t}+\varepsilon_{t t}
$$

In the equation, $\mathrm{x}_{\mathrm{it}}$ stands for the combination of all the explanatory variables; $\rho_{\mathrm{i}}$ stands for the autoregressive

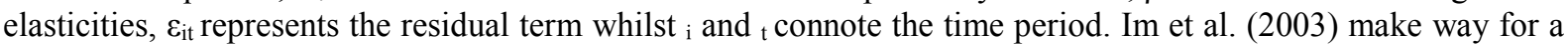
different order of serial correlation (Apergis and Payne, 2010) and subsequent the normal averaging of augmented dickey Fuller (Inglesi-Lotz, 2016) given as the equation is adopted from (Maji and Sulaiman, 2019).

$\varepsilon_{i t}=\sum_{j=1}^{n=1} \theta_{i j} \varepsilon_{i, t-1}+\varepsilon_{i t}$

Substituting Eq. (3) into Eq. (4) yield the following:

$$
y_{i t}=\rho_{i} y_{i, t-1}+\sigma_{i} x_{i t}+\varepsilon_{i t}+\sum_{j=1}^{n=1} \theta_{i j} \varepsilon_{i, t-1}+\varepsilon_{i t}
$$

In the resulting eqn. (5), pi denotes the number of lags in the ADF regression. The null hypothesis of the panel unit root tests is that each variable has a unit root and the alternate hypothesis reports that at least one of the variables in the panel is stationary in series.

After the estimation of the unit root test and all the variables prove stationary then cointegration test follows suit. The regression of time series panel data assumes either stationarity or cointegration. Cointegration tests examine the residuals of spurious regressions of non-stationary variables. In Eqn. (6), the dependent variable y is regressed on $\mathrm{x}$ to obtain the residual $\mathrm{e}_{\mathrm{it}}$. The parameter $\sigma \mathrm{i}$ is the individual effect and $\theta \mathrm{i}$ is the deterministic trend. To ascertain the Null hypothesis, $\mathrm{H}_{\mathrm{o}}$ of no cointegration, the variables are not cointegrated and the residuals will be an $\mathrm{I}(1)$ process. In conclusion, if the variables are cointegrated then the residuals in the alternative hypothesis $\mathrm{H}_{1}$ is an $\mathrm{I}(0)$ process.

At this step, the long-run equilibrium model 1 to 4 is run to estimate the dynamics among the variables to establish their effects. Fully modified ordinary least square (FMOLS) estimates long-run correlation and endogeneity by using non-parametric correction term to correct the problems that may be detected (Pedroni 2001a, $2001 \mathrm{~b}$ ). Robust least square and generalized least model are used because of the parametric and non-parametric methods incorporated in them to solve the problem of auto serial correlation, homogeneity and simultaneity. Lastly, homogeneous causality test is performed ascertain the direction of causality among the variables.

\section{Results and discussion \\ 4.1 Descriptive Statistics}

Table 3 displays the descriptive statistics of the variables considered for the study and according to the report the mean and the median are close, as well as the standard deviation, are homogeneously related. The Jarque-Bera test 
which performs skewness and Kurtosis test implies that the variables are in a normal distribution. Table 3 Descriptive Statistics

\begin{tabular}{|c|c|c|c|c|c|c|c|}
\hline & LNGDP & LNPR & LNINF & LNFDI & LNEX & LNPOP & LNUNEMP \\
\hline Mean & 7.312 & 0.775 & 1.195 & 0.539 & 3.103 & 0.952 & 1.371 \\
\hline Median & 7.353 & 0.866 & 1.194 & 0.573 & 3.177 & 0.983 & 1.437 \\
\hline Maximum & 8.746 & 3.082 & 4.288 & 4.638 & 4.412 & 2.060 & 2.511 \\
\hline Minimum & 0 & -5.638 & -3.207 & -6.089 & 0 & -1.737 & -1.255 \\
\hline Std. Dev. & 1.209 & 1.354 & 1.289 & 1.364 & 0.616 & 0.345 & 0.739 \\
\hline Skewness & -4.819 & -1.208 & 0.012 & -0.861 & -2.803 & -1.98 & -0.870 \\
\hline Kurtosis & 29.968 & 6.189 & 2.828 & 6.097 & 15.082 & 14.519 & 4.199 \\
\hline Jarque-Bera & $13840.05^{* * *}$ & $270.077 * * *$ & 0.502 & $211.959 * * *$ & $2993.592 * * *$ & $2503.840 * * *$ & $75.305 * * *$ \\
\hline
\end{tabular}

Note: $* * *$ indicates $1 \%$ significance

\subsection{Panel Unit root tests}

The study employed IPS test, Fisher tests (including Fisher-ADF test and Fisher-PP test) and Levin, lin \& chu test to find out for unit root and Table 4 report the results. From table 4, it can be reported that at level, LnPR and LnEXP were stationary with LLC and IPS tests. Also, LnFDI, LnINF, and LnPOP were stationary at level with all the tests. Since not all the variables became stationary at level, it then became necessary to perform the test at first difference and the study confirms stationarity at first difference with all the tests and variables. Therefore, the null hypothesis that there is a unit root in the variables is rejected at first difference.

Table 4 Panel Unit root tests

\begin{tabular}{llllllll}
\hline & LNGDP & LNPR & LNINF & LNFDI & LNEX & LNPOP & LNUNEMP \\
\hline level & & & & & & & \\
LLC & 0.423 & $-1.989^{* *}$ & $-4.683^{* * *}$ & $-6.272^{* * *}$ & $-1.780^{* *}$ & $-4.204^{* * *}$ & -0.316 \\
IPS & 4.387 & $-0.846^{* * *}$ & $-6.348^{* * *}$ & $-5.906^{* * *}$ & $-1.676^{* *}$ & $-9.652^{* * *}$ & 0.026 \\
ADF-Fisher & 22.974 & 37.120 & $102.565^{* * *}$ & $106.871^{* * *}$ & 39.450 & $336.229 * * *$ & 29.064 \\
PP-Fisher & 21.932 & 46.167 & $100.007^{* * *}$ & $104.197 * * *$ & 37.976 & $47.988^{* *}$ & 13.874 \\
First difference & & & & & & & \\
LLC & $-11.742^{* * *}$ & $-15.100^{* * *}$ & $-15.756^{* * *}$ & $-15.578^{* * *}$ & $-18.793^{* * *}$ & $-8.124^{* * *}$ & $-8.834 * * *$ \\
IPS & $-12.296^{* * *}$ & $-14.517^{* * *}$ & $-17.694^{* * *}$ & $-16.516^{* * *}$ & $-17.520^{* * *}$ & $-10.355^{* * *}$ & $-8.653^{* * *}$ \\
ADF-Fisher & $188.180^{* * *}$ & $224.002^{* * *}$ & $278.569^{* * *}$ & $259.124^{* * *}$ & $270.929^{* * *}$ & $172.179^{* * *}$ & $128.796^{* * *}$ \\
PP-Fisher & $204.614^{* * *}$ & $243.561^{* * *}$ & $354.202^{* * *}$ & $359.411^{* * *}$ & $300.324 * * *$ & $75.186^{* * *}$ & $116.356^{* * * *}$ \\
\hline
\end{tabular}

Note: $* * *$ indicates $1 \%$ significance, $* * *$ indicates $5 \%$ significance, $*$ indicates $10 \%$ significance

\subsection{Johansen Co-integration test}

In table 5, the results of the co-integration test are displayed and according to the results, all the variables are cointegrated hence confirming the long-run relationship that exists among the variables. From the test, at all levels, the results were $1 \%$ and $5 \%$ significant which enable the study to reject the null hypothesis that there is no cointegration among the variables.

Table 5 Panel Co-integration test

Fisher type Johansen cointegration test Hypothesized No. of CE(s)

\begin{tabular}{lll} 
Hypothesized No. of CE(s) & $\begin{array}{l}\text { Fisher Statistic } \\
\text { Trace test }\end{array}$ & $\begin{array}{l}\text { Max-eigen } \\
\text { test }\end{array}$ \\
\hline None & $743.1 * * *$ & $824.3 * * *$ \\
At most 1 & $601.3 * * *$ & $339.5 * * *$ \\
At most 2 & $351.2 * * *$ & $190.3 * * *$ \\
At most 3 & $203.2 * * *$ & $111.1 * * *$ \\
At most 4 & $118.1 * * *$ & $79.16 * * *$ \\
At most 5 & $68.04 * * *$ & $60.72 * * *$ \\
At most 6 & $46.90 * *$ & $46.90 * *$ \\
\hline Note: $* * *$ indicates $1 \%$ significance, $* * *$ indicates $5 \%$ significance, $*$ indicates $10 \%$ significance
\end{tabular}




\subsection{Correlation Matrix}

Table 6 depicts the correlation matrix of the variables and from the reports, it can be evidenced that there is no multicollinearity in the variables hence they are not highly correlated. The rule of thumb states that two independent variables should not be highly correlated with the dependent variable at a coefficient of $-/+.80$. According to the table, the highest coefficient is 0.792 ; therefore, the null hypothesis is rejected. Table 6 Correlation Matrix

\begin{tabular}{llllllll}
\hline & LNGDP & LNFDI & LNPR & LNEX & LNINF & LNPOP & LNUNEMP \\
\hline LNGDP & 1. & & & & & & \\
LNFDI & 0.128 & 1 & & & & & \\
LNPR & 0.163 & 0.308 & 1 & & & & \\
LNEX & 0.792 & 0.287 & 0.105 & 1 & & & \\
LNINF & 0.196 & 0.165 & -0.058 & 0.109 & 1 & & \\
LNPOP & -0.123 & -0.008 & 0.026 & -0.115 & -0.014 & 1 & 1 \\
LNUNEMP & 0.298 & 0.048 & 0.134 & 0.176 & 0.120 & -0.246 & 1 \\
\hline
\end{tabular}

\subsection{The effect of Personal remittances, FDI and exports on Economic growth (Individual effect)}

To assess the effects of personal remittances, FDI and exports on economic growth, the independent variables were assessed individually on economic growth establish their direct relationship and three methodologies were adopted. Table 7 shows the results of the analysis and can be reported as; LnPR showed a direct and positive effect on economic growth confirming that it increases economic growth at in all the methodologies. LnFDI and LnEXP also showed a positive and direct effect on economic growth (LnGDP) at a statistical significance level in all methodologies. By considering the macroeconomic variables, LnINF showed a negative and statistical significant effect on economic growth (LNGDP) with FMOLS but GLM and RLS showed a positive and statistically significant effect on economic growth, LnPOP showed a positive effect on LnGDP and LnUMEP also showed a positive and statistically significant effect on economic growth. This confirms that an increase in Personal remittances, Exports, FDI, unemployment, and population growth increases economic growth in the West Africa region. Inflation showed an inconsistent effect on economic growth; two (GLM and RLS) out of the three methodologies showed the positive effect at the statistical significance and one (FMOLS) showed a negative effect, also statistical significance. In contrast, since two out of three confirms positive and statistical significance then the study could statistically infer that inflation has a positive effect on economic growth.

Table 7 The effect of personal remittance, FDI and Export on economic growth

\begin{tabular}{|c|c|c|c|c|c|c|c|c|c|}
\hline \multirow{2}{*}{$\frac{\text { Variables }}{\text { LNINF }}$} & \multicolumn{2}{|c|}{ FMOLS Method } & \multirow[b]{2}{*}{-0.638} & \multirow{2}{*}{$\frac{\text { GLM }}{0.387}$} & \multirow[b]{2}{*}{0.348} & \multirow[b]{2}{*}{0.098} & \multicolumn{2}{|c|}{ Robust Least Square } & \multirow[b]{2}{*}{0.071} \\
\hline & -1.213 & -1.043 & & & & & 0.375 & 0.316 & \\
\hline & $(-29.259)^{* * *}$ & $(-25.255)^{* * *}$ & $(-15.401)^{* * *}$ & $(4.924)^{* * *}$ & $(4.368)^{* * *}$ & $(3.153)^{* *}$ & $(7.354)^{* * *}$ & $(5.921)^{* * *}$ & $(2.394)^{* *}$ \\
\hline \multirow[t]{2}{*}{ LNPOP } & 0.764 & 0.577 & 0.746 & 3.923 & 3.971 & 0.616 & 0.375 & 5.406 & 0.568 \\
\hline & $(55.306)^{* * *}$ & $(42.548)^{* * *}$ & $(54.903)^{* * *}$ & $(22.867)^{* * *}$ & $(23.367)^{* * *}$ & $(6.351)^{* * *}$ & $(7.354)^{* * *}$ & $(47.600)^{* * *}$ & $(6.115)^{* * *}$ \\
\hline \multirow[t]{2}{*}{ LNUNEMP } & 2.001 & 1.729 & 1.482 & 1.861 & 1.907 & 0.390 & 0.969 & 1.061 & 0.314 \\
\hline & $(117.148)^{* * *}$ & $(103.946)^{* * *}$ & $(84.374)^{* * *}$ & $(16.394)^{* * *}$ & $(17.156)^{* * *}$ & $(7.239)^{* * *}$ & $(13.154)^{* * *}$ & $(14.286)^{* * *}$ & $(6.098)^{* * *}$ \\
\hline \multirow[t]{2}{*}{ LNPR } & 0.189 & & & 0.181 & & & 0.226 & & \\
\hline & $(9.033)^{* * *}$ & & & $(2.389)^{* *}$ & & & $(4.582)^{* * *}$ & & \\
\hline \multirow[t]{2}{*}{ LNFDI } & & 0.877 & & & 0.141 & & & 0.083 & \\
\hline & & $(18.749)^{* * *}$ & & & $(1.864)^{*}$ & & & $(1.653)^{*}$ & \\
\hline \multirow[t]{2}{*}{ LNEX } & & & 1.064 & & & 1.939 & & & 2.000 \\
\hline & & & $(84.374)^{* * *}$ & & & $(47.438)^{* * *}$ & & & $(51.079)^{* * *}$ \\
\hline
\end{tabular}

Note: $* * *$ indicates $1 \%$ significance, $* * *$ indicates $5 \%$ significance, $*$ indicates $10 \%$ significance

\subsection{The effects of Personal remittances, FDI and Exports on economic growth: (Robust check/Combined independent variables)}

In pursuit of economic growth, a lot of factors are considered hence the study believes that considering only one variable to assess its impact on economic growth could not reveal the real economic scenario. Perhaps, the study adopted the three independent variables in one equation to assess their impact on economic growth. Table 8 reports the results of the analysis and from the report, it can be evidenced that LnPR and LnEXP have a positive and direct significant effect on economic growth. Also, LnINF and LnPOP have a positive and statistical significant effect on economic growth (LnGDP). LnFDI showed a consistent negative effect on economic growth at a statistical significance level. Moreover, LnUEMP showed inconsistent result; RLS and GLM showed positive and 
significance but FMOLS showed negative and significance. In contrast, the study could infer that LnUEMP has a positive and significant effect on economic growth in the West Africa region.

Table 8 The effects of personal remittances, FDI and exports on economic growth: Robust check

\begin{tabular}{llll}
\hline Variables & FMOLS & GLM & RLS \\
\hline LNINF & 0.024 & 0.135 & 0.105 \\
& $(1.969)^{* * *}$ & $(4.467)^{* * *}$ & $(3.649)^{* * *}$ \\
LNPOP & 0.140 & 0.533 & 0.431 \\
& $(2.979)^{* *}$ & $(5.723)^{* * *}$ & $(4.828)^{* * *}$ \\
LNUNEMP & -0.109 & 0.341 & 0.253 \\
& $(-2.592)^{* *}$ & $(6.558)^{* * *}$ & $(5.072)^{* * *}$ \\
LNPR & 0.101 & 0.110 & 0.118 \\
& $(6.985)^{* * *}$ & $(3.705)^{* * *}$ & $(4.149)^{* * *}$ \\
LNFDI & -0.023 & -0.191 & -0.170 \\
& $(-1.969)^{* *}$ & $(-6.351)^{* * *}$ & $(-5.904)^{* * *}$ \\
LNEX & 1.429 & 1.980 & 2.059 \\
& $(50.662)^{* * *}$ & $(49.787)^{* * *}$ & $(54.082)^{* * *}$ \\
\hline
\end{tabular}

Note: $* * *$ indicates $1 \%$ significance, $* * *$ indicates $5 \%$ significance, $*$ indicates $10 \%$ significance

\subsection{Homogeneous Causality test}

To ascertain the directional linkage of causality among the variables, the homogeneous causality test was employed. Table 9 reports the results, from the results the following variables have bidirectional linkage to each other; LnFDI $\leftrightarrow$ LnGDP, LnPOP $\leftrightarrow$ LnGDP, LnFDI $\leftrightarrow$ LnPR, LnPOP $\leftrightarrow$ LnPR, LnPOP LnFDI, LnPOP LnEXP, LnUMEP $\leftrightarrow$ LnPOP. The linkage implies that a variation or change in one variable homogeneously causes the other variable. There is also an existence of unidirectional linkage from LnGDP $\rightarrow$ LnPR, $\operatorname{LnGDP} \rightarrow \operatorname{LnEX}$, LnGDP $\rightarrow$ LnINF,LnGDP $\rightarrow$ LnUNEMP, $\quad$ LnPR $\rightarrow$ LnUNEMP, $\quad$ LnEXP $\rightarrow$ LnFDI, $\quad$ LnINF $\rightarrow$ LnFDI, LnUNEMP $\rightarrow$ LnFDI, LnEXP $\rightarrow$ LnINF and LnUNEMP $\rightarrow$ LnEXP. The unidirectional linkage implies that the first variable homogeneously causes the latter.

Table 9 Homogeneous Causality test

\begin{tabular}{lllll}
\hline Null Hypothesis: & W-Stat. & Zbar-Stat. & Prob. & sig. \\
\hline LNGDP does not homogeneously cause LNPR & 4.476 & 3.513 & 0.000 & $* * *$ \\
LNFDI does not homogeneously cause LNGDP & 3.750 & 2.381 & 0.017 & $* *$ \\
LNGDP does not homogeneously cause LNFDI & 4.264 & 3.183 & 0.002 & $* *$ \\
LNEX does not homogeneously cause LNGDP & 3.511 & 2.008 & 0.045 & $* *$ \\
LNGDP does not homogeneously cause LNEX & 3.333 & 1.732 & 0.083 & $*$ \\
LNGDP does not homogeneously cause LNINF & 13.018 & 16.751 & 0.000 & $* * *$ \\
LNPOP does not homogeneously cause LNGDP & 5.057 & 4.420 & 0.000 & $* * *$ \\
LNGDP does not homogeneously cause LNPOP & 12.150 & 15.475 & 0.000 & $* * *$ \\
LNGDP does not homogeneously cause LNUNEMP & 3.948 & 2.691 & 0.007 & $* *$ \\
LNFDI does not homogeneously cause LNPR & 5.420 & 4.984 & 0.000 & $* * *$ \\
LNPR does not homogeneously cause LNFDI & 3.885 & 2.592 & 0.010 & $* *$ \\
LNPOP does not homogeneously cause LNPR & 6.537 & 6.725 & 0.000 & $* * *$ \\
LNPR does not homogeneously cause LNPOP & 9.666 & 11.603 & 0.000 & $* * *$ \\
LNPR does not homogeneously cause LNUNEMP & 4.642 & 3.772 & 0.000 & $* * *$ \\
LNEX does not homogeneously cause LNFDI & 4.683 & 3.837 & 0.000 & $* * *$ \\
LNINF does not homogeneously cause LNFDI & 4.087 & 2.888 & 0.004 & $* *$ \\
LNPOP does not homogeneously cause LNFDI & 6.666 & 6.927 & 0.000 & $* * *$ \\
LNFDI does not homogeneously cause LNPOP & 5.196 & 4.635 & 0.000 & $* * *$ \\
LNUNEMP does not homogeneously cause LNFDI & 4.605 & 3.714 & 0.000 & $* * *$ \\
LNEX does not homogeneously cause LNINF & 6.803 & 7.103 & 0.000 & $* * *$ \\
LNPOP does not homogeneously cause LNEX & 3.414 & 1.858 & 0.063 & $*$ \\
LNEX does not homogeneously cause LNPOP & 10.801 & 13.373 & 0.000 & $* * *$ \\
LNUNEMP does not homogeneously cause LNEX & 5.260 & 4.735 & 0.000 & $* * *$ \\
LNUNEMP does not homogeneously cause LNPOP & 7.213 & 7.780 & 0.000 & $* * *$ \\
LNPOP does not homogeneously cause LNUNEMP & 3.322 & 1.714 & 0.086 & $*$ \\
\hline
\end{tabular}

*** indicates $1 \%$ significance, $* *$ indicates $5 \%$ significance, $*$ indicates $10 \%$ 


\section{Conclusion and recommendation}

The study examined the effect of personal remittances, FDI and export on economic growth in West Africa using panel data of 15 countries from 1991 to 2017. The study used panel methodologies such as panel unit root tests, co-integration test, correlation matrix, fully modified ordinary least square, robust least square, and generalized linear model to examine the effect of personal remittances, FDI and export on economic growth. From the outcome, it can be concluded that personal remittances and exports have strong positive and significant effect on economic growth in West Africa and FDI as an individual factor contributes positively and significantly to economic but when there are existence of personal remittances and exports in the growth model, FDI is negative and significant in West Africa. The export-led growth hypothesis is accepted in the region West Africa.

The study recommends that West Africa region should rely on FDI which are in the areas of production for export because the export-led hypothesis exists in the sample of West African. Moreover, the intensity of promoting export-driven industry should be widened to ensure the realization of more production of goods and services which intends to expand the economy in diverse ways. The study has potential policy implications as the findings indicate that remittances and export improve macroeconomic growth even when FDI inflows are not forthcoming.

\section{References}

Adams, R.H. (1991). The effects on international remittances on poverty, inequality, and development in rural Egypt. Research Report No. 96, International food policy Research Institute.

Adams, R.H., Page, J. (2003). International Migration, Remittances and Poverty in Developing countries. Policy Research Working Paper No. 3179. World Bank Poverty Reduction Group, Washington, DC. Buch, C. M., Kuckulenz, A. Le Manchee, M.-H., 2002. Worker Remittances and Capital Flows. Kiel Working Paper 1130, Kiel Institute for World Economics.

Barajas, A., Chami, R. Fullenkamp, C., Gapen, M., Montiel, P. (2009). Do workers' remittances promote economic growth? Working Paper, WP/09/153, Washington DC: International Monetary Fund.

Bugamelli, M., Paterno, F. (2011). Output growth volatility and remittances. Economica, London School of Economics and Political sciences 78 (311), 480 -500.

Calin-Adrian, C., Elena, B., Valentina, V., Daniel, S. (2018). The impact of foreign direct investments and remittances on economic growth.: A case study in Central and Eastern Europe. Sustainability 2018, 10, 238; doi:10.3390/su10010238

Catrinescu, N., Leon-Ledesma, M., Piracha, M., Bryce, Q. (2009). Remittances, Institutions, and economic growth. World Development 37, 81 -92.

Daianu, D. (2001). Balance of payments financing in Romania- The role of remittances. Romanian Center for Economic Policies, Bucharest.

Dietmar, M., Adela, S. (2017). The impact of remittances on economic growth: An econometric model. Economia $18,147-155$.

Docquier, F., Rapoport, H. (2003). Remittances and Inequality: A dynamic migration model, IZA Discussion Paper No. 808. Institute for the Study of Labor, Bonn.

Easterly, W., King, R., Levine, R., Rebelo, S. (1994). Policy, technology adoption, and growth. NBER working paper No. 4681. Cambridge, MA: MIT Press.

Gijini, A. (2013). The role of remittances on Economic growth: An empirical investigation of 12 CEE countries. International Business and Economics Research Journal 12 (2), 193 - 203.

Grossman, G., Helpman, E. (1991). Innovation and growth in the global economy. Cambridge, MA: MIT Press.

Keshmeer, K.M. (2018). Imports, remittances, direct foreign investment and economic growth in Republic of the Fiji Islands: An empirical analysis using ARDL approach. Kasetsart Journal of Social Sciences 39, 439 447.

Krueger, A. (1978). Foreign trade regimes and economic development: Liberalization attempts and consequences. Journal of Development Economy 6 (3), 447 - 437.

Leon-Ledesma, M., Piracha, M. (2001). International Migration and the role of remittances in Eastern Europe. Studies in Economics, No. 0113, Department of Economics, University of Kent.

Leon-Ledesma, M., Piracha, M. (2004). International Migration and the role of remittances in Eastern Europe. International Migration 42 (4), $65-83$

Lowell, B.L., De La Garza, R.O. (2000). The developmental role of remittances in US Latino communities and Latin American countries. A Final Project Report, Inter-American Dialogue.

Lucas, R. (1988). On the mechanics of economic development. Journal of Monetary Economics 22 (1), 3 -42.

Mundaca, G. (2009). Remittances, Financial market development, and economic growth. The case of Latin America and the Caribbean. Review of Development Economics 13 (2), $288-303$.

Narayan, P.K., Smyth, R. (2004). Trade liberalization and economic growth in Fiji: an empirical assessment using the ARDL approach. Journal of the Asia Pacific Economy 10 (1), $96-115$. 
Nur, F.M., Nor, A.A.K., Adibah, H., Azniza, A.Z., Mohd, E.A.R., Zulkifli, A.G.H. (2013). Export, Aid, Remittance and Growth: Evidence from Sudan. Procedia Economics and Finance 7, 3 -10.

OECD, 2006. International Migrant Remittances and their role in development. International migration outlook, SOPEMI. Available at: http://www.oecd.ord/els/mig/38840502.pdf

Olayungbo, D. O., Ahmod, Q. (2019). Financial innovation. Available at https://doi.org/10.1186/s40854-0190122-8.

Quibria, M.G. (1997). International Migration, Remittances and Income distribution in source country: A synthesis. Bulletin of Economic Research 491, 29 -46.

Pailwar, V.K. (2004). Foreign direct investment, resource availability and efficiency in India. In H. S. Kehal (Ed.). Foreign investment in developing countries, 112 -133. New York, NY: Palgrave Macmillan.

Ram, R. (1978). Exports and economic growth in developing countries: Evidence from time series and crosssection data. Economic Development and Cultural Change Journal 36 (3), 51 -72.

Rao, B. B., Hassan, G.M. (2012). Are the direct and indirect growth effects of remittances significant? The World Economy 35 (3), $351-372$.

Ratha, D. (2003). Worker's Remittances: An Important and Stable Source of External Development finance. Global Developing Finance 2003, World Bank, 157 - 175.

Romer, P. M. (1986). Increasing returns and long-run growth. Journal of Political Economy 94 (5), 1002 - 1007.

Roubini, N., Wachtel, P. (1999). Current account sustainability in transition economies. In M. Bleier, M. Skreb (Eds.). Balance of payments, exchange rates, and competitiveness in transition economies, 19 -93. Norwell, MA: Kluwer Academic.

Solow, R. M. (1956). A contribution to the theory of economic growth. Quarterly Journal of Economics 70 (1), $65-94$.

Swan, T. W. (1956). Economic growth and capital accumulation. Economic Record 32 (2), $334-361$.

Taylor, M. P., Sarno, L. (1999). Hot money, Accounting labels and the performance of capital flow to developing countries: An empirical investigation. Journal of Development Economics 59, 337 -364.

Terry, D.F., Jiminez-Ontiveros, F., Wilson, S.R. (2004). Beyond small change: Migrants, Remittances and Economic development. Inter-American Development Bank and Baltimore, John Hopkins University Press.

Todaro, M. P., Smith, S. C. (2006). Economic development. London, UK: Pearson Addison Wesley.

Uwaoma, G.N., Michael, J.R. (2015). FDI, Foreign aid, remittances and economic growth in developing countries. Review of Development Economics 1 (1), 100 -115.

Wan, X. (2010). A literature review on the relationship between foreign direct investment and economic growth. International Business Research 3 (1), 52 -56.

World Bank Database, World development Indicators (2017).

Zizi G. (2014). Remittances as an economic development factor. Empirical evidence from the CEE countries. Procedia Economics and Finance 10, 54-60. 